\author{
Beata Meyer \\ University of Szczecin \\ Faculty of Management and Economics of Services \\ Department of Tourism Management \\ Unit of Tourism and Health Resort Economy \\ beata.meyer@wzieu.pl
}

\title{
TOURISM VERSUS SPATIAL ORDER: MUTUAL RELATIONS
}

\begin{abstract}
The relation between tourism and the spatial environment is characterized by mutual interaction. The proliferation of tourism and massive tourism development intensifies its impact on the spatial environment, yet the focus is usually placed on environmental degradation and the resulting distortion of spatial order. Concurrently, the significance of the spatial environment, and spatial order in particular, as one of the determinants of tourism development is understated. On a theoretical plane the relation seems obvious, yet once the practical dimension is considered, it becomes at least debatable.
\end{abstract}

Key words: tourism, spatial order, tourism development determinants.

\section{INTRODUCTION}

Tourism is undeniably a spatial phenomenon and the spatial movements of tourists remain its key attribute, thus making the relation between tourism and the spatial environment obvious. This relation changes through time and nowadays, when tourism comes into focus mostly in terms of its massive volume and implicit rapid expansion in space, this relation is perceived through the impact tourism development has on the spatial environment. Since tourism shapes the spatial environment in all its dimensions, and these transformations are significant and distinctly noticeable, the other side of the relation is overlooked, i.e. the impact of the spatial environment on tourism. This relation is absolutely essential since spatial order, as one of the attributes of the environment affected, often determines the quality of the spatial environment (and spatial governance), and the ability to satisfy diverse human (also tourist) needs. The aim of this study is to identify the mutual relation between tourism and the spatial environment, with special consideration given to the significance of spatial order for the development of tourism.

\section{TOURISM VERSUS SPATIAL ORDER: HOW IT DEVELOPED}

Tourism as one of the fastest growing branches of the world economy (accounting for 8.8\% employment and
9.1\% revenue) has become one of the chief factors in shaping the global spatial environment in quantitative and qualitative terms. A constant increase in the total number of tourists (over 935 million in 2010 and one billion projected in 2012) along with diversification of their needs, and growing expectations with regard to products, attractions and services offered, triggers dynamic changes in tourism space, classically interpreted as 'part of the geographic and socio-economic space in which tourism takes place' (WARSZYŃSKA, JACKOWSKI 1978) ${ }^{1}$.

Quantitative changes can perhaps be deemed positive as the process of the disappearance of tourism space (despite its intensification) is being unquestionably overshadowed by the appearance of new tourism space and the expansion of that existing. The expansion of tourism space may be analyzed in its geographical, time- and perception-related aspects (STASIAK 2011). The stretching of tourism space in these dimensions is not as easily noticeable as its geographical expansion. By far the most discernible is the creation of new tourism spaces in areas which hitherto have not evoked tourism interest which for a number of reasons have nowadays become attractive for mass tourism². More and more frequently, the purposeful creation of tourism space is witnessed with its main (and virtually only) task being the fulfilment of tourist expectations. This is usually accompanied by the creation of new tourism attractions (or increasing the tourism appeal of existing ones), and the 
standardization of services (DURYDIWKA, DUDA-GROMADA 2011). More and more new tourism-dedicated space is being created, often in the form of tourism scenery spots or tourism attractions and theme venues appealing to specific groups of tourists. The standardization of services usually entails the development of tourism and accompanying infrastructure to provide tourists with high levels of comfort (and a sense of security) while avoiding uniformity and preserving the individual character of a given area or facility.

Parallel to changes relating to the expansion of tourism space, its internal structure is undergoing a transformation as well. This is more significant in regions where tourism is the main (or the sole) sector of the economy, which implies the subjection of its socio-economic systems to the development goals set by regional governments. In such instances, tourism becomes the chief factor determining the character of land use development and the level of spatial governance. Spatial order, in broad terms, brings together all categories of order (environmental, social, economic, spatial) and stands for the spatial organization and functioning of the socio-economic system, implements the criteria of social rationality, enables the proper operation of the system, and sustains the environment as desired. Spatial order is then interpreted as a state of structured diversity of forms and functions which enable optimal operation of the economy and society in a spatial environment, while maintaining the lowest possible number of conflicts between various organisations, and demonstrating a non-degrading effect on the natural environment (MEYER 2008). Nowadays, the significance of spatial harmony with regard to landscape aesthetics is being emphasized more frequently and it is ascertained that the aesthetic aspects of spatial order (spatial legibility, attractiveness of surroundings) are as important as its functionality and appropriacy to the structure of spatial behaviour. It is also assumed that spatial order means functionality, logic, legibility and transparency of these structures, as well as attractive design, harmony with nature, fitness for purpose, and spatial efficiency (KARWIŃSKA 2008). Since changes in the spatial environment are fast-paced, it is difficult to analyze spatial order in a static way i.e. juxtaposed against an optimal arrangement of elements ensuring the satisfactory operation of all organisations and the protection of natural resources. It is a dynamic process aimed at a continuous pursuit of an optimal state, amidst constantly changing internal and external conditions, concurrent with an attitude to get as close as possible to the optimal state in current conditions.

In areas where tourism is the predominant spatial function, often eliminating other forms of activity, it becomes the main determinant of the shape, structure and character of spatial governance and land use development, thus determining the level of spatial order. Tourists themselves play a key role in shaping the spatial order since their decisions about a holiday destination become a causative factor triggering the appearance of tourism, as broadly understood, in a given space. Moreover, tourist requirements with regard to services and type of leisure activity are of crucial significance to emerging structure and land use development plans, and determine the character of tourism space. The development of tourism, particularly the intensification of mass tourism, shapes the spatial environment in its economic, social and environmental dimensions.

The most identifiable are changes in the spatial environment occurring in the economic realm, as most often they stand for an increase of wealth in a given area which is reflected in noticeable economic growth and an improvement of living standards of the area's inhabitants. However, a simultaneous change occurs in the spatial structure which is the most visually conspicuous effect of tourism on the spatial environment. Activities relating to the creation of tourism products and services in a given area are becoming a causative factor of location processes which result in the creation of new elements in an existing spatial arrangement through the expansion (or construction from scratch) of technical and social infrastructure (MEYER 2009). Among location processes, stimulated processes are prevalent, which adjust the area's spatial structure to the needs and expectations of tourists. This category entails the development of an area's tourism infrastructure, investment enabling access to what is of tourism value and its protection (including environmental protection), as well as the creation of new tourism attractions as part of an area's tourism product. Other inductive and adaptive spatial processes are initiated concurrently, implied by the necessity to adapt the existing spatial and economic system to a new setting (with tourism of predominant significance) necessitates the reorganization of existing structures (often also their expansion) so as to enable operation of the emerging socio-economic system bringing together existing and newly-located elements. This mostly consists in adapting municipal infrastructure to tourism intensity during the high season, as the same infrastructure will be used by tourists and residents (water and sewage system, power grid, telecommunications network etc.). At a later stage, autonomous spatial processes take place, generated by an uneven distribution of tourism (and thus infrastructure). The processes are a long-term consequence of temporary actions undertaken in the spatial environment (e.g. comprising a number of activities with regard to land use designation and its consequences). Tourism activity, by inspiring new spatial 
forms and transforming (liquidating or reconstructing) existing elements, significantly determines the region's spatial development, at the same subordinating it to tourism requirements.

In the social realm, tourism induces an array of positive phenomena associated with the occupations of local inhabitants (decreased unemployment rate, vocational diversification), improved living standards or benefits stemming from good contact with tourists. However, social polarization, related to the degree of involvement in tourism handling processes and differing attitudes towards tourists, is an equally frequent phenomenon, as well as the polarization of regional developmental priorities. The adverse impact of tourism on the socio-cultural environment in tourism-attractive areas refers to its negative impact on an 'intangible' environment: acculturation and commercialization of local culture, the disappearance of genuine regional culture, destruction of social structures and the wrecking of local communities, increased consumerism, a growing number of conflicts and pathological behaviour among locals, a deteriorated quality of life. In addition the 'tangible' environment is affected: the destruction of what is of anthropogenic tourism value, changes in landscape architecture, the disappearance of the cultural landscape, and infrastructural inefficiency particularly during tourism seasons.

When it comes to the environmental realm, one may point to the positive effects of tourism development (e.g. introduction of new ideas aimed at natural environment protection), yet its negative impact is definitely wider in scope and affects all spheres constituting the environment (MEYER 2008a). Considering the 'hydrosphere', tourism contributes to the distortion of the water balance by excessive water demand leading to increased sewage generation. The amount of water used in tourism gets increasingly close to the amount consumed by industry, this situation forced by the need to meet the individual needs of tourists and tourism services, as well as the need to maintain accompanying facilities (pools, golf courses or water parks). Sources of water pollution (in addition to accommodation, catering and accompanying facilities) is water transport (sea and inland), the main source of oil-related pollution, and the dumping of waste by individual tourists and service-providing organisations. Air pollution is mostly generated by tourism-related transport, heating equipment and the operation of power-consuming devices such as air conditioning or ski infrastructure (ZARĘBA 2006). This results in the emission of increasingly large amounts of harmful compounds to the atmosphere during trips to a holiday destination and during trips in and around the destination. The effects comprise local impacts, i.e. excessive air pollution, smog or acid rain, as well as global impacts: global warming and ozone depletion. Although not well-identified as yet, the distortion of the lithosphere has consequences and is directly or indirectly linked to topography, soils and geological structure, changes in which usually arise during the construction of the tourism infrastructure: accommodation, catering, transport and accompanying facilities. It is often observed that during the process of adapting what is of tourism value to suit its needs, topography changes to facilitate transportation, underscore natural value or ensure maximum tourism attraction. The 'biosphere' is an environmental component sensitive to external influence as it responds to changes occurring in other spheres. Contamination and degradation of the latter threatens the existence of species, and in some cases leads to their extinction. Quite often a natural system damaged (or unattractive to tourists) is replaced by a new one, with more resistant species, but not necessarily indigenous to a given place.

The scope of the negative effects of tourism development, presented concisely above, being of crucial significance in many areas, clearly indicates that in regions where mass tourism is developing, one of the worst practical models of spatial governance is being implemented ${ }^{3}$. To use a metaphor, tourism can be perceived as a 'plunderer', driven by a desire to use existing spatial values to the maximum without giving consideration to the future that lies ahead. Elements of spatial development are usually used to their full capacity only during a tourism season, but the landscape and functional impact is permanent and often irreversible. Such a type of spatial governance is based on obtaining maximum instant gratification while resources are being excessively exploited, not adequately protected and elements are located in the spatial environment in a chaotic way. Concurrently, the common good that is spatial order, which is hard to quantify, is being completely overlooked though its distortion may be irreversible. Degradation of the 'tangible' environment (destruction of the natural environment, appearance of areas with chaotic land development, appearance of over-exploited areas) or the socio-cultural environment (invalidation of symbolic environments, loss of e.g. 'luxury' status) often take place as a result of various conflicts that emerge during times of rapid change. Distortion of spatial order usually occurs in the context of fast and one-sided development of an area, when spatial development becomes subordinated to only one sector of the economy (KARWIŃSKA 2008). The development of mass tourism is nowadays being compared to the development of industry, with natural resources (which not only economic sectors, but also branches within them, compete for) being the main factor generating spatial conflicts, and disrespect for land- 
scape or historical values, which along with an absence of comprehensive conceptual frameworks, leads to spatial chaos. Distortion of spatial order may become the reason for losing some (or even the majority of) values which inspired tourism and initiated its development in a given region, and most certainly it constitutes a distinct obstacle to the process of sustainable development.

There are definitely very few regions where tourism performs the role of a good host acting in a long-term perspective, accepting deferred gratification and balancing its own benefits with what is good for the community and allows spatial order to be developed within a given area. This refers mostly to regions which do not attract mass tourism, but rather alternative or specialist tourism.

\section{TOURISM VERSUS SPATIAL ORDER: DEVELOPMENT DETERMINANTS}

The relation between tourism and the spatial environment is not one-sided, with either a positive or a negative impact of tourism activity on the environment, its elements and attributes, including spatial order. It is rather a system of mutual interactions in which the potential for tourism development largely depends on diverse factors and conditions related indirectly or directly to the spatial environment. This system has a cause-and-effect nature in the sense that change to one of its elements triggers a reaction in the others. This implies that as tourism transforms the spatial environment, it affects the conditions it operates in, and this in turn changes the nature of its operation. It is a continuous process, subject to dynamic change in space and time.

Considering tourism in a variety of contexts (tourism space, tourism product, tourism economy) one may assume that determinants stimulating its growth ('stimulants') or impeding its growth ('disstimulants') are common, and only the importance and nature of their impact varies in given contexts.

In the literature, despite the conformity of most authors' views on the quantity of tourism development determinants (very large and virtually eluding comprehensive presentation) and their significance in time, a uniform classification is missing. The divisions proposed distinguish economic and non-economic factors, subjective and objective factors, demand, supply and universal factors (GAWORECKI 2003). More comprehensive classifications categorize tourism development factors into external: socio-demographic, economic, technical, political and environmental conditions; and internal: supply and demand (KUREK ed. 2008).
Comparing the significance of the main conditions shaping tourism in the past (19 ${ }^{\text {th }}$ century) and in more modern times (20 th and $21^{\text {st }}$ centuries), one may ascertain that there are several basic conditions embracing the increased awareness and wealth of societies, development of modes of transport, increased total leisure time, and the operations of organisations dedicated to the management of tourism (MEYER 2009a). Their impact on tourism development changes over the course of time and nowadays the situation has become even more complex, as the variable nature of tourism itself also plays a significant role. In a historical perspective, changes in social awareness have made the holiday trip distinctly more important as a way of spending one's leisure time (necessary for wellbeing) and have changed their perception as something that is worth spending time and money on. Further changes in awareness have resulted from rising educational standards which have contributed to the need to explore the surrounding world and encouraged people to go on intellectuallystimulating trips, cultural enrichment and the broadening of horizons. Income level (contrary to received opinion) is constantly growing and in developed countries (partly also in developing ones) does not constitute a distinct threshold separating the part of society which can afford holiday trips from that which cannot. Diversification of prices and standards of services by tourism managers (and state social policy) enables participation in tourism for a majority of those who voice such needs. At the initial stages of tourism development, increase in leisure time was induced by legal regulations forcing employers to shorten the working day and reduce the number of working days in a week; this was the result of becoming aware of the correspondence between an employee's physical and mental condition and his work efficiency, involvement and dedication. Today's increase in leisure time, as well as the amount of time spent on holiday, largely stems from a new lifestyle model promoting intense professional activity combined with equally intense leisure, both during the week and during holidays. Technical advancement in modes of transport has brought about a revolution: they are not merely a way to cover distances (as they used to be) necessary to reach the destination, but are becoming a tourism attraction per se (cruises on board luxurious liners or ferries, historic elements of railway rolling stock). Moreover, other infrastructure used by tourism is undergoing change; it is becoming more common, more versatile and more surprising in terms of spatial form. These new elements are meant to attract as many tourists as possible and fully satisfy their needs. It often happens that these inventions or new ideas enable the exploitation of what is of value for tourism, which was formerly inaccessible. The setting up of 
travel agencies in the $19^{\text {th }}$ century enabled those who were not capable of arranging a trip on their own (i.e. the majority) to travel, and the now constantly growing number of tourism operators, along with fierce competition, makes demand soar, as well as improving the variety and quality of tourism services, while stimulating price diversity.

New factors, whose significance for present-day tourism cannot be overlooked, are state policies, the economic benefits generated by tourism, the progressive increase in urban population, access to information, international circulation of money and globalization ${ }^{4}$. State policy, in broad terms, affects the demand and supply aspect of tourism. Policies aimed at ensuring a stable political situation worldwide, the disappearance of political barriers and enhancement of international safety ${ }^{5}$, boosts the demand for tourism services. Tourism policy aims at creating conducive conditions for the operation of tourism enterprises (tax concessions, preferential loans) and therefore the tourism economy, enhances the potential demand for tourism services. For many regions and states tourism has become a crucial income generator, enabling growth and enhancing wellbeing. At the same time, the size of the urban population is constantly growing and faced with an increasingly degraded natural and anthropogenic environment, it is only natural that the need to spend time in another more inspiring and friendly environment arises, contributing to the formation of highly motivated tourism needs. These are easier to satisfy in the context of technological advancement, with a free flow of information and access to media which popularize tourism and facilitate access to tourism regions and services. Such conditions as progressive globalization should not be underestimated, as they result in the facilitation of travel, the unification of tourism needs and simplified money transactions during holiday trips, while at the same time contributing to growing tourism expenditure.

Assuming that the process of creating and promoting tourism products is fundamental to the development of present day tourism ${ }^{6}$, determinants crucial to that process may be indicated. In the creation process of the tourism product, irrespective of the type of organisation it is managed by (business enterprise or region), internal determinants linked directly to the organisation can be distinguished, and external determinants consisting of a set of general conditions shaping the environment in which organisations act, and a set of specific factors related to those directly affecting the tourism products created (MEYER 2010).

Internal determinants are directly linked to the resources of the organisation creating a tourism product and to the rules governing its market opera- tions, which in turn initiate certain activities aimed to maintain or improve its market position. In the case of tourism enterprises, their resources consist of fixed and current assets, human resources and internal structure (GOŁEMBSKI ed. 2002). In the case of tourism regions, it may be assumed that the resources are equivalent to selected elements of their tourism potential, understood as all those elements of the geographical environment and human behaviour that can be used to perform or manage tourism activities (KACZMAREK, STASIAK, WŁODARCZYK 2002). Structural resources are directly linked to elements present in the region such as what is of tourism value and attractions, development of tourism facilities, accessibility, and other factors which may be conducive to tourism development (e.g. unused land for tourism-related investment). Among functional resources comprising elements directly linked to a given area, as well as those external to the area, the former can be included among factors affecting the tourism product creation process. Here the most significant are local economic factors (e.g. aid or support for tourism entrepreneurs in the region), demographic factors characterizing a given local community (available labour force, demographic structures, tourism activity to date), political and organizational conditions (comprising action undertaken by local government and other organizations to promote tourism products). As regional resources one may also consider the level of the 'co-opetition' process, that is the 'cooperative competition' of organisations responsible for the creation of a regional tourism product, as these organisations should collaborate in order to implement an attractive product (and use it properly), and at the same time compete with one another for a tourist who has decided to visit this region. The relation between organisations should be dominated by co-operation as only co-operation will allow them to put into life an attractive tourism product and ensure its long-term use (MEYER 2006).

Apart from external determinants, internal determinants affect the process of creating tourism products and these can be divided into specific and general conditions. Specific determinants consist of organisations which have a direct impact on the tourism product creation process, i.e. tourists (their number, structure, new behavioural trends or patterns etc.) and service providers (who create elements of tourism products). General determinants shape the environment in which the above-mentioned organisations operate and include such conditions as demographic (related to demographic situation, including population, biological and economic structures, household size, place of residence etc.), socio-economic (related to the level of economic growth and such indicators as gross national income, income structure 
and income distribution, real wages, unemployment rate, balance of payments), legal and organizational (regulations on tourism and tourism-related sectors), political (tourism policy) and other (globalization processes, the political and environmental situation in Poland and worldwide, progressive urbanization etc). The principles of sustainable development remain an over-riding determinant as their observance in the modern world is necessary in all sectors of the economy, and particularly in the tourism sector.

When investigating tourism development determinants from different perspectives, the issue of spatial order comes naturally to focus as an obvious prerequisite of a satisfactory holiday. Aspects of spatial order related to, for example, the quality of natural tourism, spatial development and its character, or the necessity to implement principles of sustainable growth, diversified as they are, do affect tourism development, yet spatial governance, in the broad sense of the term, is not being perceived as a determinant of tourism development (or very rarely the case). In the process of mutual interaction, the relation tourism $\rightarrow$ spatial environment is definitely predominant and its effects are distinctly noticeable in the spatial environment (distortion of spatial order), with organisations rarely realizing the importance of the inverse relation determinant, i.e. spatial environment $\rightarrow$ tourism.

\section{TOURISM AND SPATIAL ORDER: NEW TRENDS}

In the face of rapid and in a sense impetuous growth of tourism during the last decade, identification of new trends cannot be exhaustive, but rather partial and intuitive and to a large extent, extemporary. Depending on the character of the research conducted, various sets of trends referring to different aspects of tourism are indicated, however rarely do they constitute a comprehensive classification. In most (WiNIARSKI, ZdEBSKI 2008, KUREK ed. 2008, PANASIUK ed. 2011, MEYER ed. 2006) common elements can be tracked referring to such easily identifiable trends:

1. Trends in tourism supply:

- substitution (or rather supplementation as it does not seem likely that a product of leisure tourism will become entirely marginalized) of a typical $3 \times S$ tourism product (sun, sea, sand) by $3 \times \mathrm{E}$ (entertainment, excitement, education), which entails expansion of tourism space as well as the creation of new tourism attractions (e.g. theme parks, specialist and dedicated resorts) that are taking over a growing portion of tourism;
- constantly growing diversification of tourism needs, i.e. progressive diversification of needs reported when selecting a tourism trip, forcing in turn a greater diversification of tourism products, since the number of tourists demanding high comfort (development of business or incentive tourism) is rising as fast as the number who want to experience unique holidays and exotic cultures (specialist, adventure or extreme tourism).

2. Trends in tourism demand (changes in needs, preferences and motivations underlying tourism trips):

- constant increase in the number of tourists, resulting partly from the expansion of the so-called 'leisure democracy' in the sense that members of those social strata who previously did not participate in tourism (for various health-, technology- or psychology-related reasons) now participate freely (the elderly, families with very small children, the disabled);

- increase in the number of shorter tourism trips and an increase in the demand for services and their quality (even with the same number of tourists), and prioritizing safety;

- growing influence of trend-setting media (often seasonal trends) on the popularity of particular types of activities, destination regions or types of events (e.g. all-inclusive and 7/7);

- changes in preferred lifestyle, promoting a healthy and environmentally-friendly lifestyle which is reflected in the way leisure time is spent (active instead of passive leisure) and increased requirements when it comes to the quality of the environment at the destination.

3. Universal trends:

- globalization contributing to the homogenization of tourism which may result in the acceleration of tourism development, as well as its standardization and unification;

- sustainable growth, the implementation of which is not easy in practice, though well-considered and structured principles constitute a necessary component of most of the documents setting directions for the development of tourism;

- progressive informationalization and the implementation of new technologies is becoming increasingly more significant in the process of managing tourism;

- increased market competitiveness (on every level: local, regional, global);

- strong dependence between preferred tourism destinations and the current political and economic situation (terrorist attacks, military conflicts), as well as the global environmental situation (natural disasters, climate changes, the condition of natural environment). 
Among many new trends identifiable in contemporary tourism, no major premises are noticeable which would indicate that spatial order as a determinant of tourism development is gaining in importance. However, it can be assumed that trends related to the implementation of the principles of sustainable development (with its fundamental attribute being spatial order), and changes in preferred lifestyle (an environmentally-conscious attitude of tourists reflected in the demand for a high quality environment at a holiday destination) may stimulate a shift in attitudes. This is both among those in charge of creating a tourism product and among consumers of those products, and is towards realizing and emphasizing the part spatial harmony in the environment (equivalent to spatial order) plays in the overall tourism attractiveness of a given tourism venue. Such a mental shift could act as a catalyst by having respect for spatial order as a principle and promoting the attractiveness of spatial order as a kind of environment in which all human activities can be performed (in particular tourism activities) in a decidedly more effective way.

\section{SUMMARY}

The aim of recapitulation is to inspire discussion rather than formulate specific conclusions. However the following conclusion seems unquestionable spatial order, in the broad sense of the term, is not being perceived as a determinant of tourism development although some of its attributes largely define the tourism appeal of given areas. At the same time, the inverse relation carries many consequences, mostly negative. It may seem that spatial order, especially in terms of aesthetics and landscape, should be a significant determinant of choices made by tourists, favouring regions with a clear and transparent spatial arrangement. However, is it really so? Is this not just an unjustified opinion based on the assumption that systems respecting principles of spatial order are as a rule more attractive and more functional than others? As the spatial environment is perceived in a highly individual and subjective way, it eludes an objective and comprehensive evaluation, in particular with regard to the level of spatial order achieved. Choices made by mass tourists (usually determined by price, trends, and opinions of acquaintances/ family but who nevertheless are satisfied with their choices) often involve travel to places which have been chaotically developed, overloaded in terms of tourism capacity, and often visually unattractive, distinctly indicate that this trend continually becomes stronger.
In turn, it de-motivates and discourages creators of tourism products from embarking on action that would ensure spatial order in a given region. What seems crucial is the recognition of the value of spatial order both by the creators and managers of tourism products, and tourists themselves. Accepting the fact that certain standards of order undergo transformation over time, though the core remains unchanged and has an enriching function (and in many cases an enabling function), a satisfactory holiday may become an incentive to include spatial order among tourism development determinants. This, however, may be difficult to implement in a society where over $80 \%$ of citizens (2010, CBOS, Survey Report BS/134/2010) positively evaluate the existing spatial order in their place of residence, which seems surprising for anyone familiar with the standards of spatial development in Poland, and thus may suggest a low sensitivity of respondents to this aspect of the environment.

\section{FOOTNOTES}

1 In comprehensive terms, it is 'a part (sub-space) of geographical space which functionally stands out and is understood in the wider sense, that is as sub-space consisting of natural elements of the Earth (natural environment), permanent effect of human activity on this (economic environment), as well as the human environment in the social sense" (LISZEWSKI 1995), and according to the new approach, it is the part of geographic space in which tourism takes place (WŁODARCZYK 2009).

2 Apart from the expansion of the spatial environment in a technical sense (from the perspective of the area), we can also talk about the expansion of the spatial environment in a social sense (from the perspective of a tourist) when a given place is being discovered and experienced by a tourist for the first time (LISZEWSKI 2006).

3 Three main patterns have been distinguished, named in metaphorically: plunderer, good host, current administrator (KARWIŃSKA 2008).

4 An interesting idea on the determinants of contemporary tourism has been presented by Niezgoda \& Zmyślony. They distinguished civilization-related premises, urbanization, mobility, leisure time, buying power and environment (NIEZGODA, ZMYŚLONY 2003).

5 Especially after the events of 11 September 2001 which radically reordered priorities in tourism, and in particular in international travel.

${ }^{6}$ Such an assumption arises from the tendency of mass tourism to use ready-made products and that the increasing number of tourists at the same time is both the cause and the effect of the growing number and diversification of tourism products.

\section{BIBLIOGRAPHY}

DURYDIWKA M., DUDA-GROMADA K., 2011, Między autentycznościa a kreacja - tendencje i przyczyny zmian w przestrzeni turystycznej, [in:] Przestrzeń turystyczna. Czynniki, różnorodność, zmiany, M. Durydiwka, K. Duda-Gromada (ed.), Uniwersytet Warszawski, Warszawa, pp. 39-53.

GAWORECKI W., 2003, Turystyka, Wyd. Naukowe PWN, Warszawa. 
GOŁEMBSKI G. (ed.), 2002, Kompendium wiedzy o turystyce, Wyd. Naukowe PWN, Warszawa.

KACZMAREK J., STASIAK A., W€ODARCZYK B, 2002, Produkt turystyczny, albo jak organizować poznawanie świata, Wyd. Uniwersytetu Łódzkiego, Łódź.

KARWIŃSKA A., 2008, Gospodarka przestrzenna. Uwarunkowania spoteczno-kulturowe, Wyd. Naukowe PWN, Warszawa, p. 38-56.

KUREK W. (ed.), 2008, Turystyka, Wyd. Naukowe PWN, Warszawa, pp. 75-86.

LISZEWSKI S., 1995, Przestrzeń turystyczna, „Turyzm”, 5/2.

LISZEWSKI S., 2006, Nowe przestrzenie turystyczne $i$ rekreacyjne $w$ Polsce $i$ ich rola $w$ rozwoju kraju i regionu, [in:] Turystyka $w$ ujęciu przedmiotowym i przestrzennym - czlowiek, przestrzeń, przedsiębiorstwo, G. Gołembski (ed.), Wyd. Akademii Ekonomicznej w Poznaniu, Poznań, pp. 113-126.

MeYER B. (ed.), 2006, Obstuga ruchu turystycznego, Wyd. Naukowe PWN, Warszawa.

MEYER B., 2006, Regionalny produkt turystyczny jako efekt relacji pomiędzy grupami interesu, [in:] Gospodarka turystyczna a grupy interesu, S. Wodejko (ed.), SGH, Warszawa, pp. 337-347.

MEYER B., 2008a, Kształtowanie układów przestrzenno-funkcjonalnych przez turystyke, Wyd. Naukowe Uniwersytetu Szczecińskiego, Szczecin.

MEYER B., 2008b, Ład przestrzenny jako rezultat i determinanta rozwoju turystyki, [in:] Zrównoważony rozwój turystyki, S. Wodejko (ed.), SGH, Warszawa, pp. 59-71.
Meyer B., 2009a, Kształtowanie przestrzeni przez turystyke, „Ekonomiczne Problemy Turystyki", nr 12, Zeszyty Naukowe Uniwersytetu Szczecińskiego, nr 567, pp. 193-205.

MEYER B., 2009b, Historyczne i wspótczesne czynniki determinujące rozwój turystyki, „Ekonomiczne Problemy Turystyki”, nr 11, Zeszyty Naukowe Uniwersytetu Szczecińskiego, nr 521, pp. 205-219.

MEYER B., 2010, Nowe trendy w kreowaniu produktów turystycznych, "Acta Scientarum Polonorum, Oeconomia”, nr 9 (4), pp. 313-323.

NiEZGODA A., ZMYŚLONY P., 2003, Popyt turystyczny. Uwarunkowania i perspektywy rozwoju, Wyd. Akademii Ekonomicznej w Poznaniu, Poznań, pp. 116-129.

PANASIUK A. (ed.), 2011, Ekonomika turystyki i rekreacji, Wyd. Naukowe PWN, Warszawa, pp. 168-169.

STASIAK A., 2011, Wspótczesna przestrzeń turystyczna, [in:] Przestrzeń turystyczna. Czynniki, różnorodność, zmiany, M. Durydiwka, K. Duda-Gromada (ed.), Uniwersytet Warszawski, Warszawa, pp. 39-53.

WARSZYŃSKA J., JACKOWSKI A., 1978, Podstawy geografii turyzmu, PWN, Warszawa.

WINIARSKI R., ZDEBSKI J., 2008, Psychologia turystyki, Wydawnictwa Akademickie i Profesjonalne, Warszawa.

WŁODARCZYK B., 2009, Przestrzeń turystyczna. Istota, koncepcje, determinanty rozwoju, Wyd. Uniwersytetu Łódzkiego, Łódź.

ZARĘBA D., 2006, Ekoturystyka, Wyd. Naukowe PWN, Warszawa. 